\title{
PENGARUH MANAGEMENT CONTROL TERHADAP PENERAPAN STANDAR GLOVING DI OK IGD RSUP SANGLAH
}

\author{
Desak Gede Yenny Apriani ${ }^{1}$, Ni Wayan Alit Puspa Dewi \\ ${ }^{1}$ Program Studi Keperawatan Ners STIKES Advaita Medika Tabanan \\ Email: yennyapriani2004@gmail.com
}

\begin{abstract}
Abstrak
Latar belakang dan tujuan: Teknik closed gloving merupakan metode terbaik untuk mencegah kontaminasi selama memakai sarung tangan steril. Teknik closed gloving dijadikan sebagai standar gloving di kamar operasi. Penerapan standar gloving di kamar operasi sangat penting untuk dilakukan dan diperlukan sistem yang mampu membuat standar ini tetap berjalan yaitu dengan adanya controlling. Salah satu yang mampu melakukan pengawasan terhadap penerapan standar ini adalah perawat. Tujuan dari penelitian ini adalah untuk menganalisis pengaruh management control terhadap penerapan standar gloving di OK IGD RSUP Sanglah.

Metode: Desain penelitian ini adalah pre experiment dengan post test design with control group. Teknik sampling yang digunakan adalah consecutive sampling dengan jumlah sampel adalah 24 orang yang dibagi menjadi 2 kelompok yaitu kelompok kontrol sebanyak 12 orang dan kelompok intervensi sebanyak 12 orang. Management control diberikan hanya pada kelompok intervensi. Data penerapan standar gloving dianalisis menggunakan uji Chi Square.

Hasil:Berdasarkan uji statistik yang menggunakan uji Chi Square didapatkan $p$ value sebesar 0,001 dengan $p$ value yang kurang dari 0,05 maka hipotesis diterima.

Simpulan: terdapat pengaruh management control terhadap penerapan standar gloving di OK IGD RSUP Sanglah
\end{abstract}

Kata kunci :Management control, gloving, Standar Oprasional Prosedur (SOP)

\section{PENDAHULUAN}

Pembedahan merupakan salah satu tindakan medis yang penting dalam pelayanan kesehatan. Tindakan pembedahan bertujuan untuk menyelamatkan nyawa, mencegah kecacatan dan komplikasi. Namun demikian, pembedahan yang dilakukan juga dapat menimbulkan komplikasi yang dapat membahayakan nyawa (Haynes, et al. 2011). Salah satu komplikasi dari pembedahan adalah infeksi paska pembedahan. Kejadian infeksi paska operasi tergantung pada banyak faktor, baik faktor yang terkait dengan pasien, tim bedah dan terutama adalah kemungkinan kontaminasi luka operasi selama proses pembedahan. Meski infeksi luka operasi bersifat multifaktorial, tim bedah memiliki peran kunci dalam pencegahan faktor-faktor penyebab infeksi yang berhubungan dengan prosedur bedah selama periode pra dan intraoperatif (Oliveira \& Gama, 2016).

Salah satu upaya yang harus dilakukan untuk mencegah terjadinya infeksi luka operasi adalah dengan menerapkan teknik aseptik di kamar operasi. Selain melakukan cuci tangan bedah menggunakan cairan antiseptik, memakai baju steril (gowning) teknik gloving menjadi salah satu hal penting yang perlu mendapat perhatian. Menurut Oliveira \& Gama (2016), tangan dari tim bedah adalah hal yang memegang peranan penting dan perlu mendapat perhatian, karena terdapat kemungkinan adanya kolonisasi mikrobakterial sebagai akibat seringnya kontak dengan banyak pasien. Menurut Oliveira \& Gama (2016) selain melakukan cuci tangan bedah penggunaan sarung tangan setril adalah tindakan yang harus diperhatikan karena teknik penggunaan 
sarung tangan steril yang benar akan mampu menjadi barier pencegahan transmisi mikroorganisme. Terdapat 3 teknik gloving yaitu open gloving, closed gloving dan assisted gloving. Teknik closed gloving merupakan metode terbaik untuk mencegah kontaminasi selama memakai sarung tangan steril karena jari tangan dan pergelangan tangan tidak kontak langsung dengan sarung tangan steril. Maka dari itu closed gloving dijadikan sebagai standar gloving di kamar operasi (Long, 2014).

Hasil penelitian Hahipour et al (2006) dalam Turkanto et al (2012) menunjukkan bahwa 50-67\% terjadi robekan sarung tangan pada operator kamar operasi selama proses pembedahan yang menyebabkan transmisi mikroorganisme dari tangan operator ke dalam area pembedahan. Salah satu penyebab adanya robekan sarung tangan dan transmisi mikroorganisme dapat disebabkan oleh pelaksanaan gloving yang tidak sesuai standar. Penerapan standar gloving di kamar operasi sangat penting untuk dilakukan dan diperlukan sistem yang mampu membuat standar ini tetap berjalan yaitu dengan adanya controlling. Salah satu yang mampu melakukan pengawasan terhadap penerapan standar ini adalah perawat.

Profesi keperawatan merupakan profesi yang berperan penting dalam pelayanan kesehatan. Keperawatan merupakan salah satu profesi yang memberikan pelayanan keperawatan dan menyelengarakan pelayanan keperawatan yang bermutu di rumah sakit. Perawat sebagai salah satu anggota yang membawa persfektif yang unik dalam interdisiplin tim. Perawat membantu dan memfasilitasi pasien untuk mendapat pelayanan kesehatan dan asuhan keperawatan. Perawat berperan sebagai penghubung penting dalam suatu rumah sakit. Salah satu contohnya perawat kamar bedah. Peran perawat kamar bedah bertanggung jawab secara klinis dan berfungsi sebagai scrub nurse (instrumentator) atau perawat sirkuler.

Berdasarkan hasil studi pendahuluan di ruang OK IGD RSUP Sanglah pada 8 Agustus 2017 didapatkan bahwa dari 8 orang anggota tim bedah $50 \%$ menggunakan teknik open gloving, 37,5\% menggunakan metode closed gloving dan 12,5\% menggunakan metode assisted gloving. Sebanyak 62,5\% tidak menerapkan standar gloving di kamar operasi. Berdasarkan hal tersebut peneliti tertarik untuk meneliti tentang pengaruh management control terhadap penerapan standar gloving pada tim bedah di OK IGD RSUP Sanglah Denpasar.

\section{METODE PENELITIAN}

Desain penelitian ini adalah pre experiment dengan post test design with control group. Teknik sampling yang digunakan adalah consecutive sampling dengan jumlah sampel adalah 24 orang yang dibagi menjadi 2 kelompok yaitu kelompok kontrol sebanyak 12 orang dan kelompok intervensi sebanyak 12 orang. Sejumlah 12 responden pada kelompok intervensi dilakukan management control oleh perawat sirkuler sebelum responden memakai sarung tangan steril. Perawat sirkuler mengingatkan tentang pemakaian teknik closed gloving sebagai standar gloving. Selanjutnya responden diobservasi tentang teknik gloving yang digunakan. Management control diberikan hanya pada kelompok intervensi. Data penerapan standar gloving dianalisis menggunakan uji Chi Square.

\section{HASIL DAN PEMBAHASAN}

Penelitian ini dilakukan selama lima hari sejak tanggal 27 Agustus 2017 hingga 1 September 2017. Penelitian ini dilakukan di Ruang OK Instalasi Gawat Darurat Rumah Sakit Umum Pusat (RSUP) Sanglah Denpasar.

Sebagian besar responden dalam penelitian ini berjenis kelamin laki-laki yaitu sejumlah 19 orang $(79,2 \%)$ Berdasarkan tabel 1 menunjukkan bahwa sebagian besar responden berprofesi sebagai dokter residen yaitu sejumlah 17 orang $(70,8 \%)$.

Berdasarkan tabel 3 menunjukkan bahwa sebagian besar responden pada kelompok intervensi (sebanyak 75\%) melakukan gloving sesuai dengan standar. Pada tabel 4 menunjukkan sebagian besar responden pada 
kelompok kontrol melakukan gloving tidak sesuai standar yaitu sebanyak $91,7 \%$.

Berdasarkan tabel 5 dari kedua kelompok kontrol dan intervensi terdapat 10 responden yang melakukan penerapan standar gloving dimana sebagian besar responden yang menerapkan standar gloving adalah kelompok intervensi (sebesar 90\%). Berdasarkan uji statistik menggunakan uji Chi Square dengan tingkat kepercayaan 95\% didapatkan nilai $p$ value sebesar 0,001 . Berdasarkan nilai signifikansi yang kurang dari 0,05 dapat disimpulkan bahwa hipotesis diterima, terdapat pengaruh management control terhadap penerapan standar gloving di OK IGD RSUP Sanglah Denpasar.

Tabel 1 Karakteristik Responden Berdasarkan Jenis Kelamin

\begin{tabular}{lrr}
\hline \multicolumn{1}{c}{ Jenis Kelamin } & Frekuensi & Persentase (\%) \\
\hline Laki-laki & 19 & 79,2 \\
Perempuan & 5 & 20,8 \\
\hline Total & 24 & $100 \%$ \\
\hline
\end{tabular}

Tabel. 2 Karakteristik Responden Berdasarkan Profesi

\begin{tabular}{lrr}
\hline \multicolumn{1}{c}{ Profesi } & Frekuensi & Persentase $(\%)$ \\
\hline Perawat & 4 & 16,7 \\
Dokter residen & 17 & 70,8 \\
Mahasiswa Keperawatan & 2 & 8,3 \\
Bidan & 1 & 4,2 \\
\hline Total & 24 & 100.0 \\
\hline
\end{tabular}

Tabel 3 Penerapan Standar Gloving pada Kelompok Intervensi

\begin{tabular}{crr}
\hline Penerapan Standar Gloving & Frekuensi & Persentase (\%) \\
\hline Sesuai standar & 9 & $75 \%$ \\
Tidak sesuai standar & 3 & $25 \%$ \\
\hline \multicolumn{1}{c}{ Total } & 12 & $100 \%$ \\
\hline
\end{tabular}

Tabel 4 Penerapan Standar Gloving pada Kelompok Kontrol

\begin{tabular}{lrr}
\multicolumn{1}{c}{ Penerapan Standar Gloving } & Frekuensi & Persentase (\%) \\
\hline Sesuai standar & 1 & $8,3 \%$ \\
Tidak sesuai standar & 11 & $91,7 \%$ \\
\hline Total & 12 & $100 \%$ \\
\hline
\end{tabular}


Tabel 5 Perbedaan Penerapan Standar Gloving pada Kelompok Kontrol dan Kelompok Intervensi

\begin{tabular}{lccccc}
\hline \multirow{2}{*}{ Sensitivitas post } & \multicolumn{4}{c}{ Penerapan Standar Gloving } & \multirow{2}{*}{$\begin{array}{l}p \\
\text { value }\end{array}$} \\
\cline { 2 - 5 } & \multicolumn{2}{c}{ Sesuai standar } & \multicolumn{2}{c}{ Tidak sesuai standar } & \\
\cline { 2 - 5 } & $\mathrm{f}$ & $\%$ & $\mathrm{f}$ & $\%$ & 0,001 \\
\hline $\begin{array}{l}\text { Kelompok } \\
\text { Kontrol }\end{array}$ & 1 & $10 \%$ & 11 & $78,6 \%$ & \\
\hline $\begin{array}{l}\text { Kelompok } \\
\text { Intervensi }\end{array}$ & 9 & $90 \%$ & 3 & $21,6 \%$ & \\
\hline Total & 10 & $100 \%$ & 14 & $100 \%$ & \\
\hline
\end{tabular}

Kelompok intervensi sebagian besar responden melakukan gloving sesuai dengan standar. Hanya 3 responden yang melakukan gloving tidak sesuai dengan standar. Berdasarkan hasil observasi penulis, dari 3 responden yang tidak menerapkan standar gloving, 2 responden yang tidak menggunakan teknik closed gloving dikarenakan lengan gaun operasi yang terlalu pendek sehingga tidak mampu menutupi jarijari tangan dengan baik dan membuat responden kesulitan untuk menggunakan teknik closed gloving, sedangkan satu responden mengatakan tidak bisa menggunakan teknik closed gloving.

Sebagian besar responden pada kelompok kontrol tidak melakukan gloving sesuai dengan standar, terdapat 11 responden yang melakukan gloving tidak menggunakan teknik closed gloving. Berdasarkan observasi peneliti 9 responden dalam kelompok kontrol menggunakan teknik open gloving dan 2 responden menggunakan teknik assisted gloving.

Penerapan standar gloving lebih banyak dilakukan oleh responden pada kelompok intervensi daripada kelompok kontrol. Hal ini dapat disebabkan oleh karena dilakukan management control oleh perawat sirkuler sebelum tim bedah melakukan gloving. Berdasarkan uji statistik menggunakan uji Chi Square dengan tingkat kepercayaan 95\% didapatkan nilai signifikansi yang kurang dari 0,05 sehingga dapat disimpulkan bahwa terdapat pengaruh management control terhadap penerapan standar gloving di OK IGD RSUP Sanglah Denpasar.

Hasil penelitian ini sejalan dengan hasil penelitan Rotti et al (2014) dalam penelitian yang berjudul "Hubungan Fungsi
Manajemen Kepala Ruangan dengan Pelaksanaan Pencegahan dan Pengendalian Infeksi di Ruang Rawat Inap Rumah Sakit Umum Pusat Prof. R.D. Kondou Manado" menunjukkan bahwa terdapat hubungan antara fungsi managemen dengan pelaksanaan dan pengendalian infeksi. Hasil penelitian ini juga sejalan dengan Parmin (2010) dalam penelitian yang berjudul "Hubungan Pelaksanaan Fungsi Manajemen Kepala Ruangan dengan Motivasi Perawat Pelaksana di Ruang Rawat Inap RSUP Undata Palu" yang menunjukkan bahwa variabel fungsi manajemen kepala ruangan yang paling berhubungan dengan motivasi adalah fungsi pengarahan dan fungsi pengawasan (controlling).

Management control akan memungkinkan rencana dilaksanakan oleh sumber daya secara efektif dan efisien sesuai standar yang ditetapkan. Pengawasan yang sistematis akan berdampak pada pelayanan asuhan yang sesuai standar sehingga pelayanan yang diberikan lebih efektif dan efisien (Marquis \& Hhouston, 2000 dalam Parmin, 2010). Adanya pengawasan dapat mengendalikan prilaku seseorang (Parmin, 2010). Oleh sebab itu pelaksanaan management control perlu dilaksanakan dan ditingkatkan pelaksanaannya agar meningkatkan motivasi tim bedah untuk melaksanakan gloving sesuai dengan standar.

\section{KESIMPULAN}

Sebagian besar responden pada kelompok intervensi melakukan gloving sesuai dengan standar. Sebagian kecil responden pada kelompok kontrol melakukan gloving sesuai dengan standar. Terdapat pengaruh management control terhadap 
penerapan standar gloving di OK IGD RSUP Sanglah Denpasar

\section{REFERENSI}

Allegranzi, dkk.2009. Role of hand hygiene in healthcare-associated infection prevention

Depkes RI. 2010.Surveilans infeksi di rumah sakit. Depkes RI:Jakarta

Krediet, A.C dkk. 2011. Hand-hygiene practices in the operating theatre: an observational study. British Journal of Anaesthesia

Labrague dkk .2012.Operating room Nurses, Knowledge and Practice of Steril Technique

Long JB. 2014.Surgical case management. In: KB Frey, T Ross, eds. Surgical Technology for the Surgical Technologist: A Positive Care Approach, 4th ed. Clifton Park, NY: Cengage Learning

Marquis dan Huston.2010. Kepemimpinan dan manajemen keperawatan. Teori dan Aplikasi.Jakarta:EGC.
Masloman, A.P. 2015. Analisis Pelaksanaan Pencegahan dan Pengendalian Infeksi di Kamar Operasi RSUD Dr. Samratulangi Tondano. Ejournal Universitas Samratulangi Vol 5

Oliveira, Adriana Cristina de \& Gama. 2016. Surgical antisepsis practices and use of surgical gloves as a potential risk factors to intraoperative contamination. Universidade Federal de Minas Gerai

Parmin .2010.Hubungan Pelaksanaan Fungsi Manajemen Kepala Ruangan dengan Motivasi Perawat Pelaksana di Ruang Rawat Inap RSUP Undata Palu

Potter dan Perry.2009. Fundamentals of nursing. Fundamental keperawatan. Salemba Medika Edisi 7. Jakarta

Robbins, Stephen P \& Coulter.2007. Perilaku Organisasi Buku 1.Jakarta: Salemba Empat 